\title{
SURGICAL TREATMENT OF POST BURN DEFORMITIES OF ORAL COMMISSURE AND LOWER LIP
}

\author{
Ahmed Sabry Ahmed \\ Reconstructive and Plastic surgery Division, General Surgery Department, Faculty of Medicine, Al-Azhar University \\ Hospital, Damietta, Egypt.
}

\begin{abstract}
Background: The lip is affected by burn injury. The complications of post burn scarring of the lip are often resulting in aesthetic deformity and psychological troubles in patient's particularly adult females. A burn disturbed the aesthetic features and lines of the lip. The aim of work is to choose the suitable method of treating post burn deformities of oral commissure and lower lip. .

Subjects and Methods: We admitted 24 patients to our hospital from June 2007 to July 2012. They were complaining of deformity of lower lip, contracted commissure either as a single lesion or as a part of face or as a part of the body. Age of our patients ranged from 3-60 years with average age 24.38 years. The surgical methods may be full thickness skin grafts (nine cases), tissue expansion (13) cases, local flap (one case) and scar revision (one case).

Results: We noticed that there were three elements that determine the surgical methods of treating deformities of lower lip: condition of the surrounding skin, extent and shape. We have already discussed and evaluated the various techniques of reconstruction. 19 out of 24 patients proved to be a success.

Conclusion: full thickness skin grafts have a certain percentage of morbidity in the form of partial loss. The possibility of contamination is inevitable in some patients with bad eating habits.
\end{abstract}

Key words: Post burn, Deformity, Lip, Oral commissure

Corresponding author: Ahmed Sabry Ahmed.

Received: 1 September 2015

Telephone: +201223838250

Email: dasahm@yahoo.com

Accepted: 29 October 2015

\section{INTRODUCTION}

T he lower lip, together with the chin, is an important aesthetic unit of the face. Thermal injury produces obliteration of chinlip depression and ectropion of lower lip exposing the teeth , producing constant dribbling of saliva, affecting normal speech and preventing closure of the mouth ${ }^{[1]}$ .Burned lips are rarely an isolated injury, and in most cases they constitute part of a burned fac. Many factors may aggravate the problem, e.g. increased burn depth, late presentation, incorrect primary treatment, incorrect aftercare and surgical reconstruction, and the timing of surgical reconstruction ${ }^{[2,3] \text {. }}$

The surgical treatment of contracted oral commissure is functional and aesthetic. The functional target includes the restoration of oral competence and sufficient articulation through the reestablishment of a functioning orbicularis oris muscle circle. Aesthetic target includes restoration of symmetry of lips in static in addition to kinetic positions, with sufficient stomal diameter, besides avoiding ugly scars ${ }^{[4]}$.

The Reconstruction of post burn perioral tissue defects represents major challenges for reconstructive surgeons. This is due to needing full supply of dermis and soft tissue; fasciocutaneous flaps are indicated on resurfacing defects in perioral regions. The free radial forearm flap is considered the best flap having thin pliable skin and long vascular pedicle so it is used for reconstructing the perioral area, ${ }^{[5]}$. The disadvantage of this flap is high donor site morbidity ${ }^{[6]}$. The other option is to reconstruct post-burn facial deformities is using pedicled flap or a free flap of the back skin. The dorsal skin is only donor site in reconstructing the whole face because it provides large amount of skin ${ }^{[7]}$. 


\section{Aim of work}

The aim of treatment was restoration of the lower lip to its original upright position in opposition to the upper lip, oral competence and oral apertures.

\section{PATIENTS AND METHODS}

We admit 24 patients to our hospital from June 2007 to July 2012. They were complaining of post burn deformity of lower lip in the form of: lip contractures, scarred lip, and ectropion, contracture of commissure as single lesions or part of scarred face or as a part of generalized body burned. Their ages ranged from 3-60 years with mean age 24.38 years. There are 8 males and 16 females .The interval from the initial injury to the time of reconstruction is from six months to three years. The causes of burn are thermal (19 cases), flame (two cases), electrical (two cases) and one case of chemical origin.

As regard the affected site ;isolated lower lip deformity (eight cases),as part of scared face $^{[12]}$ and a three cases as a part of the body burned .The contracted commissure unilateral (four cases) and bilateral (nine cases).All treated by V-Y advancement flap. Evaluation of patients included their medical condition, assessment of surgical options and deformity analysis...

Each deformed lip was photographed at the time of presentation, pre-operatively early and late postoperatively.

Patients were classified according to method of reconstruction into:

Group 1: full thickness skin graft (nine cases) (fig.1a).

Group 2: tissue expansion (13 cases) (fig.2a). Group3: local flap (staircase) one case (fig.3). Group 4: revision (one case)

Technique: All operations were carried out with oral inhalation anesthesia.

Lower lip cheiloplasty was designed for bordering; using a full-skin graft for the skin of the chin area after excision of scarred tissue. The defect was covered full thickness skin graft with tie over dressing in nine cases. In case of using tissue expanders we insert expander in the first stage. In the second stage the scared tissue was excised then covers the defect by a flap obtained from the expanded skin.

Stepladder flap was used in one case and scar revision in another case...

Commissuroplasty:

The place of the neocommissure was determined by taking the distance from a point in the middle of philtral column to the commissure on the non affected side. This measurement is then transformed by calipers to the affected side...A pen is used for outlining the points of the new commissure. This is determined by a perpendicular line dropped from mid-pupil up to $1 \mathrm{~cm}$ lateral to commissure. Then infiltrate with a local anesthetic; full-thickness incisions are made with no. 15 blade. The $\mathrm{v}$ shaped scar tissue on the lateral side of the vermilion is dissected sharply and excised exposing the oral mucosa and orbicularis oris (fig.4b) .We preserve muscle to get contour and functional competence of the lips. A vertical incision is made in the buccal mucosa to $1 \mathrm{~cm}$ lateral to skin incision, after which curved vertical incisions are made. We release contracted commissure and reconstruct by adopting a V$\mathrm{Y}$ advancement flap and a mucosal transposition flap. During elevation of these flaps, orbicularis oris muscle realignment was made with absorbable sutures. The patients were operated under local anesthesia. A fullthickness horizontal incision through the oral commissure was made to restore the aperture. The incision was extended, to match the oral commissure of the nonoperated side. The sutures were removed on the $5^{\text {th }}$ day.

We evaluate our results depending on the presence or absence of complications.

\section{RESULTS}

Group 1: full thickness skin graft (nine cases). Partial take in two cases; one case healed spontaneously and the other case covered by full thickness skin graft (Fig.1b).

Group2: tissue expansion (13 cases).In this group implant failure in one case and infection was occurred in another case followed by removal of expander (Fig. 2b).

Group3: local flap (staircase) one case (Fig.3). In this group microstomia and 
corrected by $\mathrm{v}-\mathrm{y}$ advancement flap to release commissure.

Group 4: revision (one case) (Table1).

Good results are obtained in $79 \%$ of patients as in (table1).Results are also depicted (Figs..1-4).
Follow up period ranged between three months to five years

(Average: 17.5 months

Table 1: clinical series

\begin{tabular}{|c|c|c|c|c|c|c|c|c|}
\hline No. & Sex & $\begin{array}{l}\text { Age } \\
\text { (year) }\end{array}$ & Site & Etiology & Procedure & $\begin{array}{l}\text { Complicati } \\
\text { on }\end{array}$ & Result & $\begin{array}{l}\text { Secondary } \\
\text { procedures }\end{array}$ \\
\hline 1 & Male & 9 & Scar lower lip & $\begin{array}{l}\text { Post thermal } \\
\text { burn }\end{array}$ & $\begin{array}{l}\text { Full } \\
\text { thickness } \\
\text { skin graft }\end{array}$ & None & Good & \\
\hline 2 & Female & 57 & $\begin{array}{l}\text { Scar face bilateral } \\
\text { commissure } \\
\text { contracted }\end{array}$ & $\begin{array}{l}\text { Post thermal } \\
\text { burn }\end{array}$ & $\begin{array}{l}\text { Expander v- } \\
\mathrm{y}\end{array}$ & None & Good & \\
\hline 3 & Female & 3 & $\begin{array}{l}\text { Scar face rt. } \\
\text { commissure }\end{array}$ & $\begin{array}{l}\text { Post-flame } \\
\text { burn }\end{array}$ & $\begin{array}{l}\text { Expander v- } \\
\mathrm{y}\end{array}$ & None & Very good & \\
\hline 4 & Female & 40 & $\begin{array}{l}\text { Scar face bilateral } \\
\text { commissure ectropion } \\
\text { lower lip }\end{array}$ & $\begin{array}{l}\text { Post thermal } \\
\text { burn }\end{array}$ & $\begin{array}{l}\text { Expander v- } \\
\mathrm{y}\end{array}$ & None & Good & \\
\hline 5 & Male & 60 & $\begin{array}{l}\text { Scar face rt. } \\
\text { commissure }\end{array}$ & $\begin{array}{l}\text { Post- flame } \\
\text { burn }\end{array}$ & $\begin{array}{l}\text { Excision of } \\
\text { scar and full } \\
\text { thickness } \\
\text { graft }\end{array}$ & None & Good & \\
\hline 6 & Male & 45 & $\begin{array}{l}\text { Scar face bilateral } \\
\text { commissure ectropion } \\
\text { lower lip }\end{array}$ & $\begin{array}{l}\text { Post thermal } \\
\text { burn }\end{array}$ & $\begin{array}{l}\text { Expander } \\
\text { and } v-y \text { for } \\
\text { commissure }\end{array}$ & none & good & \\
\hline 7 & Female & 9 & $\begin{array}{l}\text { Scar face bilateral } \\
\text { commissure ectropion } \\
\text { lower lip }\end{array}$ & $\begin{array}{l}\text { Post thermal } \\
\text { burn }\end{array}$ & $\begin{array}{l}\text { Expander } \\
\text { and } v-y \text { for } \\
\text { commissure }\end{array}$ & None & Good & \\
\hline 8 & Male & 40 & $\begin{array}{l}\text { bilateral commissure } \\
\text { ectropion lower lip }\end{array}$ & $\begin{array}{l}\text { Post thermal } \\
\text { burn }\end{array}$ & $\begin{array}{l}\text { Full } \\
\text { thickness } \\
\text { graft and v-y } \\
\text { for } \\
\text { commissure }\end{array}$ & None & Good & \\
\hline 9 & Female & 18 & $\begin{array}{l}\text { Scar face bilateral } \\
\text { commissure ectropion } \\
\text { lower lip }\end{array}$ & $\begin{array}{l}\text { Post thermal } \\
\text { burn }\end{array}$ & $\begin{array}{l}\text { Expander } \\
\text { and } v \text {-y for } \\
\text { commissure }\end{array}$ & None & Good & \\
\hline 10 & Female & 5 & $\begin{array}{l}\text { Part of general body } \\
\text { burn }\end{array}$ & $\begin{array}{l}\text { Post thermal } \\
\text { burn }\end{array}$ & $\begin{array}{l}\text { Full } \\
\text { thickness } \\
\text { graft }\end{array}$ & Partial take & fair & $\begin{array}{l}\text { Healed } \\
\text { spontaneousl } \\
\text { y }\end{array}$ \\
\hline 11 & Female & 35 & $\begin{array}{l}\text { Scar face bilateral } \\
\text { commissure ectropion } \\
\text { lower lip }\end{array}$ & $\begin{array}{l}\text { Post thermal } \\
\text { burn }\end{array}$ & $\begin{array}{l}\text { Full } \\
\text { thickness } \\
\text { graft v-y }\end{array}$ & None & Very good & \\
\hline 12 & Female & 6 & $\begin{array}{l}\text { bilateral commissure } \\
\text { ectropion lower lip }\end{array}$ & $\begin{array}{l}\text { Post thermal } \\
\text { burn }\end{array}$ & $\begin{array}{l}\text { Expander v- } \\
\mathrm{y}\end{array}$ & $\begin{array}{l}\text { Exposure } \\
\text { of expander }\end{array}$ & Fair & \\
\hline 13 & Female & 11 & $\begin{array}{l}\text { Scar-ectropion lower } \\
\text { lip }\end{array}$ & $\begin{array}{l}\text { Post thermal } \\
\text { burn }\end{array}$ & Expander & None & Very good & \\
\hline 14 & Female & 50 & Scar face-commissure & $\begin{array}{l}\text { Post thermal } \\
\text { burn }\end{array}$ & $v-y$ & None & Good & \\
\hline 15 & Male & 40 & $\begin{array}{l}\text { Scar face-rt. } \\
\text { commissure }\end{array}$ & $\begin{array}{l}\text { Post } \\
\text { chemical } \\
\text { burn }\end{array}$ & $\begin{array}{l}\text { Expander v- } \\
\mathrm{y}\end{array}$ & None & Good & \\
\hline 16 & Female & 5 & $\begin{array}{l}\text { Scar face-bilateral. } \\
\text { commissure }\end{array}$ & $\begin{array}{l}\text { Post thermal } \\
\text { burn }\end{array}$ & $\begin{array}{l}\text { Expander } \\
\mathrm{v}-\mathrm{y} \text { for } \\
\text { commissure }\end{array}$ & $\begin{array}{l}\text { Implant } \\
\text { failure }\end{array}$ & Fair & $\begin{array}{l}\text { Full } \\
\text { thickness } \\
\text { skin graft }\end{array}$ \\
\hline 17 & Female & 32 & $\begin{array}{l}\text { Part of general body } \\
\text { burn }\end{array}$ & $\begin{array}{l}\text { Post thermal } \\
\text { burn }\end{array}$ & $\begin{array}{l}\text { Full } \\
\text { thickness } \\
\text { graft }\end{array}$ & Partial take & fair & $\begin{array}{l}\text { Full } \\
\text { thickness } \\
\text { skin Graft }\end{array}$ \\
\hline 18 & Male & 15 & Ectropion lower lip & $\begin{array}{l}\text { Post thermal } \\
\text { burn }\end{array}$ & $\begin{array}{l}\text { Full } \\
\text { thickness } \\
\text { graft }\end{array}$ & None & Good & \\
\hline 19 & Female & 8 & Defect of lower lip & $\begin{array}{l}\text { Pos } \\
\text { electrical } \\
\text { burn }\end{array}$ & $\begin{array}{l}\text { Staircase } \\
\text { flap }\end{array}$ & $\begin{array}{l}\text { microstomi } \\
\text { a }\end{array}$ & Fair & $\begin{array}{l}\mathrm{v}-\mathrm{y} \quad \text { for } \\
\text { commissure }\end{array}$ \\
\hline
\end{tabular}




\begin{tabular}{|c|c|c|c|c|c|c|c|c|}
\hline 20 & Male & 23 & Scar lower lip & $\begin{array}{l}\text { Post thermal } \\
\text { burn }\end{array}$ & Revision & None & Good & \\
\hline 21 & Female & 9 & Rt.commissure & $\begin{array}{l}\text { Post } \\
\text { electrical } \\
\text { burn }\end{array}$ & $v-y$ & None & Good & \\
\hline 22 & Female & 11 & Part of burned body & $\begin{array}{l}\text { Post thermal } \\
\text { burn }\end{array}$ & Expander & $\begin{array}{l}\text { Infection } \\
\text { and } \\
\text { removale of } \\
\text { expander }\end{array}$ & Fair & $\begin{array}{l}\text { Full } \\
\text { thickness } \\
\text { skin graft }\end{array}$ \\
\hline 23 & Female & 30 & Ectropion of lower lip & $\begin{array}{l}\text { Post thermal } \\
\text { burn }\end{array}$ & $\begin{array}{l}\text { Full } \\
\text { thickness } \\
\text { graft }\end{array}$ & none & good & \\
\hline 24 & Male & 24 & $\begin{array}{l}\text { Scar face ectropion } \\
\text { lower lip Rt. } \\
\text { commissure } \\
\text { contractures }\end{array}$ & $\begin{array}{l}\text { Post thermal } \\
\text { burn }\end{array}$ & $\begin{array}{l}\text { Expander v- } \\
\text { y }\end{array}$ & None & Good & \\
\hline
\end{tabular}

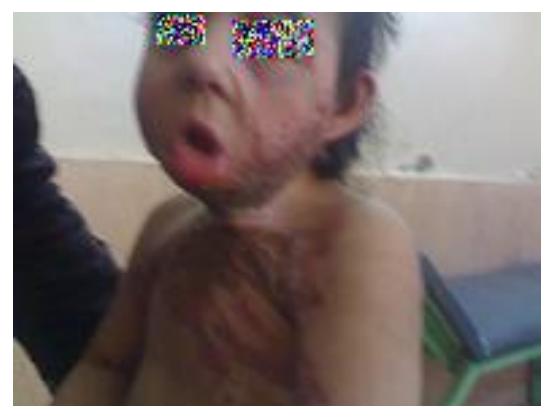

A

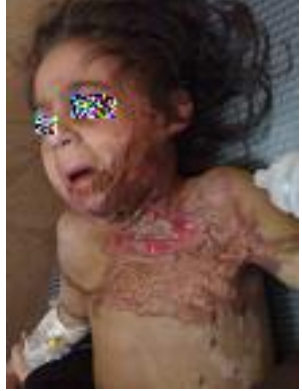

B

Fig.1a: A preoperative view showing a child 4 year-old with post burn ectropion of lower lip with exposure of teeth and lower gum.

B: postoperative view showing release of ectropion with full thickness skin graft.

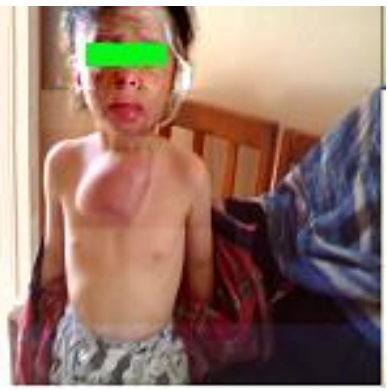

A

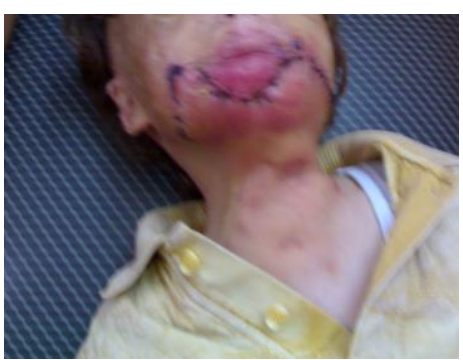

B

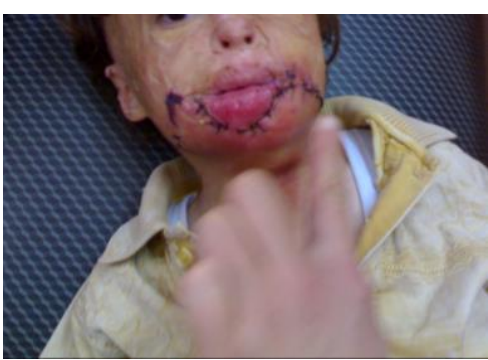

C

Fig.2a: A five year old female with post thermal burn with ectropion lower lip with tissue expander was inserted B and c: postoperative view after expanded flap advancement to correct ectropion of lower lip

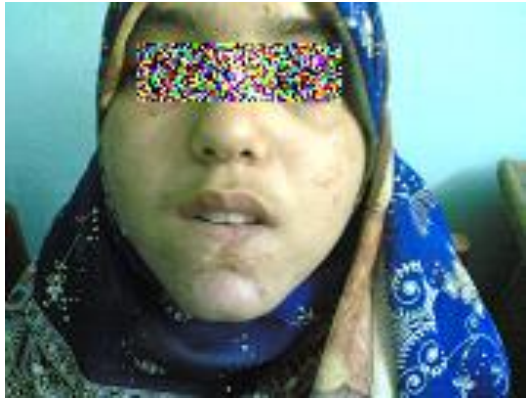

A

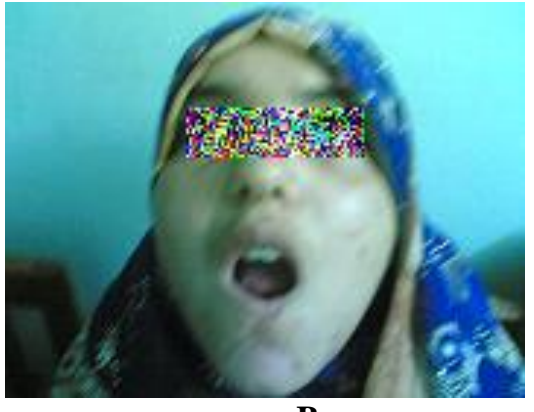

B

Fig.3: A 9 year old female with post electrical burn with defect of lower lip reconstructed with staircase flap a: postoperative view mouth at rest

B: postoperative view with opening her mouth. 


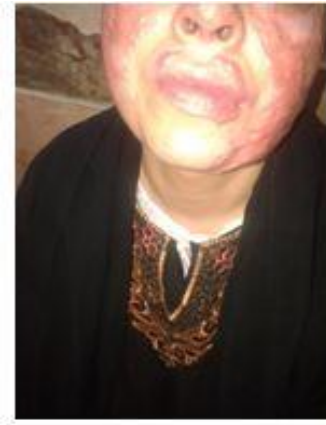

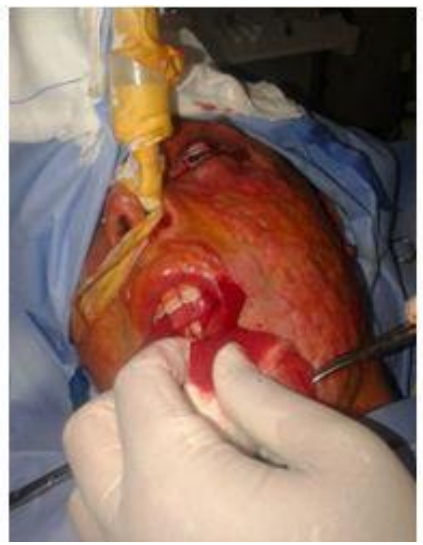

B

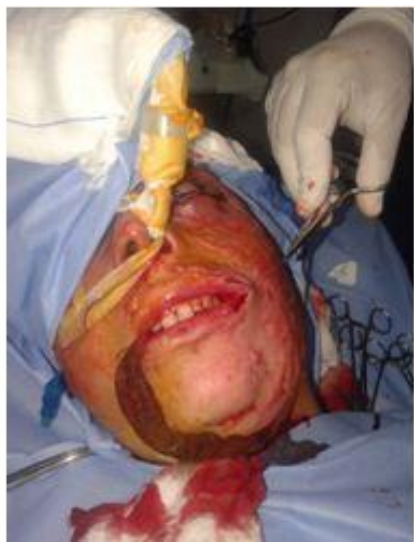

C

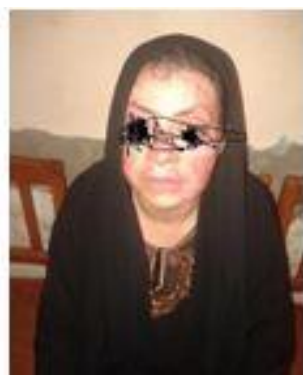

D

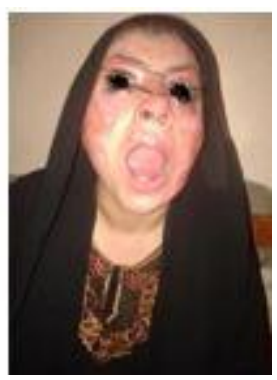

$\mathbf{E}$

Fig. 4: A 50 year-old female with post thermal burn scarred face and contracted left commissure: (A) Preoperative view at rest; (B) A triangle tissue at a commissure was excised; (C) Intraoperative view closure of v-y flap (D)

Postoperative view at rest of the mouth; (E) postoperative view at opening of the mouth.

\section{DISCUSSION}

Burn scars in the lips and disfigured lip aesthetics are commonly treated with psychological assurance and training for perfect camouflaging, especially with regard to female burn victims. Some cases with major deformities that go beyond simply aesthetic considerations are treated surgically either by release of contractures and by local flaps for reconstruction of lip defects or by Commissuroplasty. Partial- and full-thickness skin grafts are commonly used for resurfacing scarred perioral regions, including lip borders and lines, as also for reconstructing post-burn deformed lower lips and, above all, for releasing contracted and everted lips. Skin graft losses are higher in the case of fullthickness skin grafts around the mouth opening because of contamination by food and fluids ${ }^{[8]}$.

Microstomia following burns of the face remains a significant challenge requiring the plastic surgeon to seek creative reconstructive options ${ }^{9}$. Anatomy of the oral commissure and modiolus is very sophisticated to meet their functions so creation after burn injury is more difficult to recreate ${ }^{[9]}$. Reconstruction thus requires thoughtful planning. The goals of reconstruction are both functional And aesthetic and the surgical techniques employed are often overlapping ${ }^{[10 ; 11]}$. Garson., ${ }^{[12]}$, discussed the aspect of the effect of prevention, which in the lip aesthetics of 
perioral burns reduces the incidence of disfigurement due to inadequate or inappropriate treatment of this kind of burn, which is most commonly part of face or body burns. However, he added that in deep burns deformity could be inevitable despite good initial treatment, local care of burned lips, and aftercare of healed scars. He judged that the progress made in burns management in the last 40 years had contributed to the improvement of functional and aesthetic prognosis. He stated that early surgical intervention had been modified as a conservative approach. Skin grafts and distant flaps were used to reconstruct extensive perioral defect due to the limited availability of surrounding donor tissues [13; 14].

In order to obtain complete release of contracted scar, the borders of the dissected scars should have free divergence for enough mouth opening; on the other hand linear incision of immature, rigid and thick scars is insufficient because linear incision restricts edge. The Y-shaped scar incision with limbs of about $3 \mathrm{~mm}$ allows free scars' borders' divergence and complete contracture release. After mouth opening, as a rule, a trapeze shaped wound is formed, which corresponds to the realize and form of the scar's surface deficit. After the contracted scars are dissected and the contracture is released, the scar edges become a continuation of the vermilion borders of the upper and lower lips that often are scarred and lose their redness.

The reconstruction of extensive post burn deformity of the lower face presents a challenge to plastic surgeons. This is due to many factors such as a structural bad vascularity, maturity of the scar tissue, extreme tensile strength of the scar, and unstable skin coverage ${ }^{[15]}$.

Facial reconstruction by tissue expansion is advantageous because the generated skin is superior to that obtained from distant locations on the body, thereby surpassing the efficacy of conventional methods. However, The efficacy of this technique can further be increased with certain modification ${ }^{[16]}$.

\section{CONCLUSIONS}

The technique's disadvantages are as follows: full thickness skin grafts have a certain percentage of morbidity in the form of partial loss, which may alter the aesthetic results; the possibility of contamination is inevitable in some patients with bad eating habits that could affect such a delicate surgical procedure.

\section{REFERENCES}

1. Sawhney CP. Management of burns in India. In Jackson, I. T. and Sommerlad, B. C. (Eds) Recent advances in plastic surgery. London, Churchill Livingstone. No. 1996;5, P. 207,

2. Cardoso ER, Amonoo-Kuofi HS, Hawary MB. Post-burn deformity of lip-chin complex: A method to restore the mentolabial sulcus. Int. J. Oral Maxillofac. Surg., 1995; 24: 14850.

3. Kobus K. Late repair of facial burns. Ann. Plast. Surg., 1980; 5: 191-204.

4. Robotti E, Righi B, Carminati M, Ortelli L, Bonfirraro PP, Devalle L. Bocchiotti MA. Oral commissure reconstruction with orbicularis oris elastic musculomucosal flaps. Journal of Plastic, Reconstructive \& Aesthetic Surgery 2009; $1-9$.

5. Lee JW, Jang YC, Oh SJ. Esthetic and functional reconstruction for burn deformities of the lower lip and chin with free radial forearm flap. Ann. Plast. Surg 2006;56: 384- 6.

6. Richardson D, Fisher SE, Vaughan ED, Brown JS. Radial forearm flap donor-site complications and morbidity: a prospective study. Plast Reconstr. Surg. 1997;99: 109-15,

7. Sakurai H, Takeuchi M, Fujiwara O, Soejima K, Yamaki T, Kono T, et al. Total face reconstruction with one expanded free flap. Surg Technol Int; 2005; 14: 329-33,

8. Saadeldeen WM. Chieloplasty in post burn deformed lip. Annals of Burns and Fire Disasters 2009; 31(1):.63.

9. Ayhan M, Aytug Z, Deren O, Karantinaci B, Gorgu M. An alternative treatment for post burn microstomia treatment: Composite auricular lobule graft for oral commissure reconstruction. Burns 2006; 32: 380-4.

10. Monteiro DI, Horta R, Silva P, Amarante JM, Silva A. Asimple "fishtail flap" for surgical correction of microstomia. J Craniofac Surg; 2011; 22:2292-4.

11. Koymen R, Gulses A, Karacayli U, Aydintug, YS. Treatment of microstomia with 
commissuro-plasties and semidynamic acrylic splints. Oral Surg Oral Med Oral Pathol Oral Radiol Endod; 2009; 107: 503-7.

12. Garson S. Les lèvres brûlées. Ann. Chirurgie Plastique Esthétique 2002; 47: 547-559.

13. Feldman JJ. Facial burns. In McCarthy JG. editor. Plastic surgery, vol. 3. Philadelphia, PA: Saunders 1990; 153- 236.
14. Barton FE, Byrd HS. Acquired deformities of the nose. In: McCarthy JG, editor. Plastic surgery, vol. 3. Philadelphia, PA: Saunders; 1990: 1924.

15. Grishkevich MV. Postburn microstomia: Anatomy and elimination with trapeze-flap plasty burns 2011; 37: 484- 489.

16. Argenta LC, Marks MW. Mathes plastic surgery. 2nd ed. vol. 1. Saunders; 2006; 545. 